\title{
Volumetric Behaviour of Binary Liquid Mixtures at a Temperature of 303.15 K
}

\author{
Mohammad A. Wahab, ${ }^{\dagger}$ M. Azhar Ali, $+\underset{+}{\dagger}$ and Mohammad A Mottaleb ${ }^{*}$ \\ Deparment of Polymer Science and Enginesing. College of Engineering, Pastm Vatonal Lniversity, Pasan 609-735, Korea \\ "Deparment of Chemisnu. Limetsity of Rajshahi, Rajshahi 6205, Banglatesh

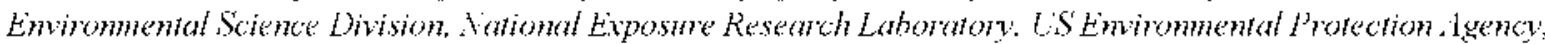 \\ P.O. Box, 93+78, Las I'egas. II'89193-3+78. LS1 \\ Received Januany 22. 2002
}

\begin{abstract}
Excess nolar volumes $\left(\mathrm{V}_{\mathrm{m}}{ }^{\mathrm{L}}\right)$ of binary liquid mixtures: $\mathrm{xC}_{6} \mathrm{H}_{5} \mathrm{Cl}_{3}+\left(\mathrm{l}-\mathrm{x}_{1}\right) \mathrm{CH}_{3} \mathrm{CN}$ or $+\left(1-\mathrm{x}_{1}\right) \mathrm{C}_{6} \mathrm{~L}_{5} \mathrm{NO}_{2}$, or $+\left(1-\mathrm{x}_{1}\right) \mathrm{C}_{2} \mathrm{l}_{5} \mathrm{NO}_{2}$ have been determined as a function of mole fraction of $\mathrm{C}_{6} \mathrm{l}_{5} \mathrm{C}_{3} \mathrm{I}_{3}(\mathrm{~s})$ at a temperature of $303.15 \mathrm{~K}$ over a entire range of composition. The densities of the binary liquid mixtures were determined by pycnometrically. The $V_{n}{ }^{1}$ values of the mixtures have been found to be negative over the whole composition in order of $\mathrm{C}_{6} \mathrm{~L}_{5} \mathrm{CI}_{3}+\mathrm{C}_{6} \mathrm{I}_{5} \mathrm{NO}_{2}<\mathrm{C}_{6} \mathrm{I}_{5} \mathrm{Cl}_{3}+\mathrm{Cl}_{5} \mathrm{CN}$, and $\left.\angle \mathrm{C}_{6} \mathrm{I}_{5} \mathrm{Cl}_{3}+\mathrm{C}_{2} \mathrm{H}_{5} \mathrm{NO}\right)_{2}$. The negative magnitude of $V_{m}{ }^{b}$ suggests the presence of intemolecular interaction in the three binary liquid nistures.
\end{abstract}

Keywords : Fixess molar volumes, Toluene, Nitrohenzene, Nitroethane, Acetonitrile

\section{Introduction}

For the past two decades. a considerable progress has been made in theoretical understanding of liquid-liquid binary mixture. Besides the theoretical importance. the knowledge of physicochemical properties of multi-components mixtures is indispensable for many chemical process industries. Examples are the petroleum, petrochemical etc. are commonly used in industries where plysicochemical processes are involyed to handle the mixtures of hydrocarbons, alcohols, aldehydes. ketones etc. Importantly: for accurate designing equipment it is necessary to know the interaction between the components of mixtures. Plys sicochemical analy sis method can be used for getting sound information for a specific interaction between the components and the structure of the binary liquid mixtures. The thermodynamic studies of binary solutions have attracted much attention of scientists and experimental data on a number of systems are available from review and publications. ${ }^{1-12}$

In the framework of a research work. which aims to study the thermodynamic properties of binary liquid mixtures with different components. We also reported some works of binary mixtures. ${ }^{13-19}$ This paper will describe the excess molar volumes of $\mathrm{x}_{6} \mathrm{H}_{3} \mathrm{CH}_{3}+\left(1-\mathrm{x}_{1}\right) \mathrm{CH}_{3} \mathrm{CN}$, or $\left(1-\mathrm{x}_{1}\right)$ $\mathrm{C}_{3} \mathrm{H}_{3} \mathrm{NO}_{2}$, or $\left(1-\mathrm{x}_{3}\right) \mathrm{C}_{2} \mathrm{H}_{5} \mathrm{NO}_{2}$ in obtaining the interaction information of all the binary liquid mixtures. The components considered in the paper are $\mathrm{C}_{6} \mathrm{H}_{3} \mathrm{CH}_{3}, \mathrm{CH}_{3} \mathrm{CN} . \mathrm{C}_{6} \mathrm{H}_{5} \mathrm{NO}_{2}$. and $\mathrm{C}_{2} \mathrm{H}_{5} \mathrm{NO}_{2}$ at the temperature $303.15 \mathrm{~K}$. This is a continuation of our previous investigation.

\section{Experimental Section}

Materials and Procedure. The toluene (purity 99.5\%.

"Comesponding Author, LPNNRC: Postdoctoral Research Associalc, lax: +1-702-798-2142, L-mail: Moltaleb.Mohammadia: epamail.epa.gor
Merck), acetonitrile (purity $99 \%$, Fluka), nitrobenzene (purity 99.5\%, Merck) and nitroethane (purity 99.5\%. Methesoni) were used. The densities of the pure components and binary mixtures were measured by pycnometrically and were reported elsewhere. ${ }^{15,1 ?}$ Special attention was given to avoid the evaporation of solutions after preparation. The purity of chemicals was checked by comparing with their densities with literature values, ${ }^{\Upsilon 0,21}$ and obtained values gave a good agreement with reported values. ${ }^{\wedge}$ The comparative results are shown in Table 1 . The values of density of the chemicals at the working temperature are. however not available in the literature. we obtained those values at working temperature by plotting the reported values, and considering the density as a linear function of temperature.

The $V_{31}{ }^{\mathrm{E}}$ of different binary mixtures were calculated from the measured values of the densities $(\rho)$ of all the liquid binary mixtures using equation ( 1 ):

$$
\mathrm{V}_{\mathrm{m}}{ }^{\mathrm{L}} / \mathrm{cml}^{3} \mathrm{~mol}^{1}=\left(\mathrm{x}_{1} \mathrm{M}_{1}+\mathrm{x}_{2} \mathrm{M}_{2} \mathrm{y} / \rho_{\mathrm{m}}-\mathrm{x}_{1} \mathrm{M}_{1} / \rho_{l}-\mathrm{x}_{2} \mathrm{M}_{2} / \rho_{2}\right.
$$

Where $M_{1}$ and $M_{2}$ represent the molar masses of components $\mathrm{L}$ and 2 . respectively. The $\mathrm{x}_{1}$ and $\mathrm{x}_{2}$ are the mole fractions of 1 and 2 components having densities $\rho_{1}$ and $\rho_{2}$. respectively: The $\rho_{\mathrm{n}}$ is experimentally observed density of the bimary liquid mixtures. All measurements were carried out in a thermostatically controlled and well-stirred water bath with a temperature accuracy of $\pm 0.0 \mathrm{l}{ }^{\circ} \mathrm{C}$. read on Beckmamn thermometer.

\section{Results}

Table 2 represents the experimental results for $\mathrm{V}_{\mathrm{tu}}{ }^{\mathrm{F}}$ obtained from liquid mixtures: $\mathrm{xC}_{6} \mathrm{H}_{5} \mathrm{CH}_{3}+\left(1-\mathrm{x}_{1}\right) \mathrm{CH}_{3} \mathrm{CN}$. or (1$\left.\mathrm{x}_{1}\right) \mathrm{C}_{6} \mathrm{H}_{5} \mathrm{NO}_{2}$ or $\left(\mathrm{I}-\mathrm{x}_{1}\right) \mathrm{C}_{2} \mathrm{H}_{5} \mathrm{NO}_{2}$ systems at a temperature of $303.15 \mathrm{~K}$. The observed results of $\mathrm{V}_{\mathrm{m}}{ }^{\mathrm{F}}$ were fitted by least square method to four parameter RedlichKister ${ }^{2 . i}$ equation (2) as follow: 
Table 1. Comparison between experimental and literature values of densities $\left(\mathrm{o} \mathrm{cm}^{-3}\right)$ at a temperature of $20^{\circ} \mathrm{C}$

\begin{tabular}{|c|c|c|c|c|c|c|c|}
\hline \multicolumn{2}{|c|}{$\mathrm{C}_{6} \mathrm{H}_{4} \mathrm{CH}_{3}$} & \multicolumn{2}{|c|}{$\mathrm{CH}_{3} \mathrm{CN}$} & \multicolumn{2}{|c|}{$\mathrm{C}_{6} \mathrm{H}_{4} \mathrm{NO}_{2}$} & \multicolumn{2}{|c|}{$\mathrm{C}_{2} \mathrm{H}_{5} \mathrm{NO}_{2}$} \\
\hline lixperimental & l.iteralure & Jixperimental & Literature & Jixperimental & Literature & lixperimental & literalure \\
\hline 0.8669 & 0.8660 & 0.7855 & 0.7857 & 1.26136 & 1.20 .37 & 1.0440 & 1.0444 \\
\hline
\end{tabular}

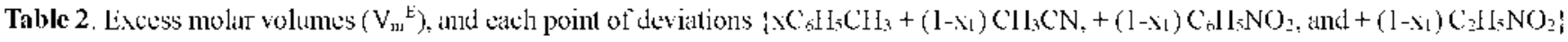

\begin{tabular}{|c|c|c|c|c|c|c|c|c|}
\hline \multicolumn{3}{|c|}{$\mathrm{C}_{4} \mathrm{l}_{5} \mathrm{Cll}_{3}$ । $\mathrm{Cl}_{3} \mathrm{C} \mathrm{N}$ mixlure } & \multicolumn{3}{|c|}{$\mathrm{C}_{4} \mathrm{H}_{4} \mathrm{CH}_{3} \cdot \mathrm{C}_{6} \mathrm{H}_{5} \mathrm{NO}_{2}$ mixture } & \multicolumn{3}{|c|}{ 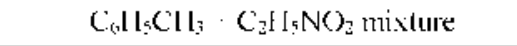 } \\
\hline $\begin{array}{l}\text { Mole fiaction } \\
\text { (x) }\end{array}$ & $\begin{array}{c}V_{\mathrm{rr}}^{\mathrm{E}} \\
\left.\mathrm{cm}^{3}: 1\right] \mathrm{l} / \mathrm{l}\end{array}$ & $\begin{array}{c}\text { Deviation } \\
\text { emol }^{3}: m_{0}\end{array}$ & $\begin{array}{l}\text { Mole fraction } \\
\text { (x) }\end{array}$ & $\begin{array}{c}V_{11}^{E} \\
\mathrm{~cm}^{3} \mathrm{~mol}\end{array}$ & $\begin{array}{l}\text { Deviation } \\
\mathrm{cm}^{3} \text { mol }\end{array}$ & $\begin{array}{c}\text { Mole } \\
\text { lraction }(x)\end{array}$ & $\begin{array}{c}V_{\mathrm{tth}}{ }^{\mathrm{t}} \\
\mathrm{cm}^{3}: \operatorname{mol}\end{array}$ & $\begin{array}{c}\text { Devialion } \\
\mathrm{cm}^{3} \text { mol }\end{array}$ \\
\hline 0.0999 & -0.1260 & -0.0020 & 0.1099 & -6.2556 & 0.00133 & 0.10000 & -0.0584 & 0.0010 \\
\hline 0.1990 & $-0.246]$ & $-0.0(0)] 8$ & 0.2012 & $-(1.4865$ & -0.0028 & 0.20004 & -0.0971 & $-(0.00)(0)$ \\
\hline 0.3006 & -0.3363 & 0.0057 & 0.3014 & -0.6568 & -0.00618 & 0.2994 & -0.1 .361 & -0.00003 \\
\hline 0.4016 & $-(0.4013$ & 0.0018 & 0.4015 & $-(1.7199$ & $0.00(1) 5$ & 0.3976 & -0.1720 & 0.0033 \\
\hline 0.5004 & -0.4286 & -0.00080 & 0.4987 & -0.6888 & -0.0012 & 0.4989 & -0.2092 & -0.00010 \\
\hline 0.5979 & -0.3968 & $-0.000] 0$ & 0.5981 & -0.5808 & 0.0062 & 0.5995 & -0.2254 & -0.003 .3 \\
\hline 0.6964 & -0.3259 & 0.0062 & 0.7005 & -() .4559 & $-0.00+2$ & 0.6984 & -0.2082 & -0.00006 \\
\hline 0.7985 & -0.2331 & 0.00017 & 0.8043 & -0.3156 & -0.0037 & 0.7974 & -0.1541 & 0.0064 \\
\hline 0.8967 & -0.1247 & $-0.6 k+38$ & 0.8980 & -() .1792 & 0.0040 & 0.8986 & -0.0893 & -0.0050 \\
\hline
\end{tabular}

Table 3. The values of the parameter's $\Lambda_{j}\left(\Lambda_{0}, \Lambda_{1}, \Lambda_{2}\right.$ and $\left.\Lambda_{3}\right)$ and the standatd deviation ( $S$ ) for all the three binaty mixtures of the Redlich-Kister exuation al a temperalure of $303.15 \mathrm{~K}$

\begin{tabular}{|c|c|c|c|c|c|}
\hline $\mathrm{XC}_{4} \mathrm{H}_{5} \mathrm{CH}_{3}$ & $\Lambda_{1 \cdots}$ & $\begin{array}{c}\mathrm{A}_{\mathrm{I}} \\
\mathrm{cmol}^{3} \mathrm{~mol}\end{array}$ & $\begin{array}{c}\mathrm{A}_{2-} \\
\mathrm{em}^{3} \mathrm{~mol}\end{array}$ & $\frac{A_{3} .}{\mathrm{cm}^{3}: \mathrm{mol}}$ & $\begin{array}{l}S \\
\perp\end{array}$ \\
\hline$(1-x) C_{3} C N$ & -1.6825 & 0.082 .3 & 0.5359 & -0.0507 & 0.00568 \\
\hline$\left.(1-x) C_{n} I H N O\right)_{2}$ & -2.7464 & 1.4824 & 0.6958 & -1.7530 & 0.00047 \\
\hline$(1-x) C_{2} I H N O=$ & -0.8340 & 0.4977 & $0.1(1) 47$ & -0.4717 & 0.06425 \\
\hline
\end{tabular}

$$
\mathrm{V}_{\mathrm{un}}{ }^{\mathrm{F}} / \mathrm{cm}^{3} \mathrm{~mol}^{-1}=\mathrm{x}_{\mathrm{l}}\left(\mathrm{l}-\mathrm{x}_{\mathrm{l}}\right) \sum_{j=0}^{3}\left(\mathrm{Aj}\left(2 \mathrm{x}_{\mathrm{l}}-\mathrm{l}\right)^{j}\right.
$$

The values of the parameter $\mathrm{Aj}$. obtained by a least square method with all points. are summarized in the Table 2 along with each point of deriations. The parameters $\mathrm{Aj}$ and standard deviation are given in the Table 3. For all the mixtures, $\mathrm{S}\left(\mathrm{V}_{\mathrm{m}}{ }^{\mathrm{F}}\right)<0.005 \mathrm{~cm}^{7} \mathrm{~mol}^{-1}$ showing a good accuracy. attainable with the pycnometer used in this research.

\section{Discussion}

Figure $\mathrm{l}$ indicates the $\mathrm{V}_{11}{ }^{\mathrm{E}}$ of all three mixtures: $\mathrm{xC}_{6} \mathrm{H}_{3} \mathrm{CH}_{3}$ $+\left(1-\mathrm{x}_{1}\right) \mathrm{CH}_{3} \mathrm{CN}_{2} \mathrm{xC}_{6} \mathrm{H}_{2} \mathrm{CH}_{3}+\left(1-\mathrm{x}_{1}\right) \mathrm{C}_{4} \mathrm{H}_{3} \mathrm{NO}_{2}$. and $\mathrm{xC}_{6} \mathrm{H}_{3} \mathrm{CH}_{3}$ $+\left(1-\mathrm{x}_{1}\right) \mathrm{C}_{2} \mathrm{H}_{3} \mathrm{NO}_{2}$ as a function of mole fraction of $\mathrm{C}_{6} \mathrm{H}_{2} \mathrm{CH}_{3}$ (x). The $\mathrm{V}_{\mathrm{m}}{ }^{\mathrm{F}}$ for the $\mathrm{C}_{6} \mathrm{H}_{2} \mathrm{CH}_{3}+\mathrm{CH}_{3} \mathrm{CN}$ mixture in Figure $\mathrm{I}$ decrease with increase of $\mathrm{C}_{4} \mathrm{H}_{3} \mathrm{CH}_{3}$ concentration and pass through a point at about $\times\left(\mathrm{C}_{4} \mathrm{H}_{2} \mathrm{CH}_{4}\right)=0.5004$ and then increases when the concentration of $\mathrm{C}_{6} \mathrm{H}_{i} \mathrm{CH}_{3}$ component is increased in the mixture. For liquid mixtures: $\mathrm{C}_{6} \mathrm{H}_{3} \mathrm{CH}_{3}+$ $\mathrm{C}_{6} \mathrm{H}_{5} \mathrm{NO}_{2}$ and $\mathrm{C}_{4} \mathrm{H}_{2} \mathrm{CH}_{3}+\mathrm{C}_{2} \mathrm{H}_{3} \mathrm{NO}_{2}$ st stems, the $\mathrm{V}_{m}{ }^{\mathrm{F}}$ decrease with increasing the mole fraction of $\mathrm{C}_{4} \mathrm{H}_{3} \mathrm{CH}_{3}(\mathrm{x})$ and pass through a minimum value at about $\mathrm{x}\left(\mathrm{C}_{4} \mathrm{H}_{2} \mathrm{CH}_{7}\right)=0.4987$ and 0.5995 . respectively. And then it increases with mole fraction of $\mathrm{C}_{6} \mathrm{H}_{2} \mathrm{CH}_{3}$. The sequence of the magnitude of excess molar volume against the mole fraction of the $\mathrm{C}_{6} \mathrm{H}_{3} \mathrm{CH}_{3}$ for

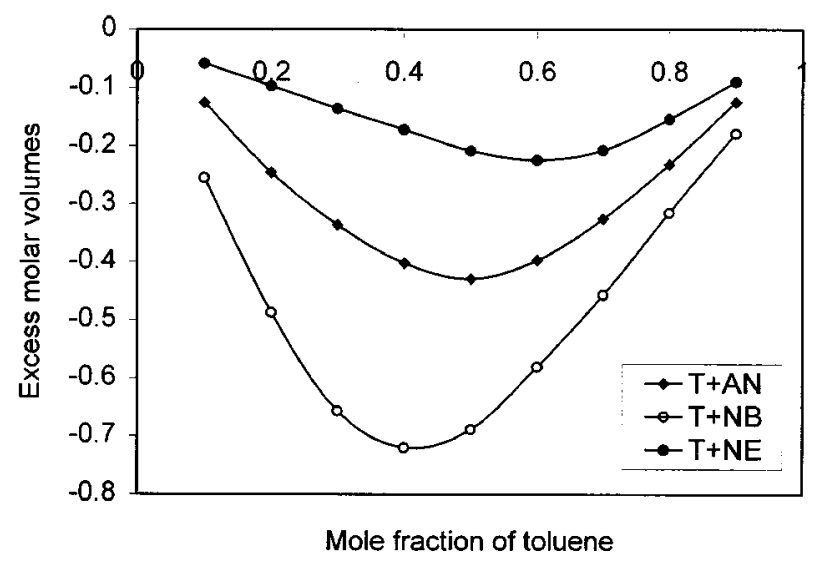

Figure 1. Lifluct of excess molar volumes ( $V_{\text {tth }}{ }^{5}$ ) on composition of the mixtures: $\mathrm{x}_{1} \mathrm{C}_{2} \mathrm{H}_{5} \mathrm{CH}_{3}$ and $\left(\mathrm{I}-\mathrm{x}_{3}\right) \mathrm{CI}_{3} \mathrm{CN}$. $\mathrm{x}_{1} \mathrm{C}_{3} \mathrm{I}_{5} \mathrm{CH}_{3}$ and $(\mathrm{I}-$ $\left.\mathrm{x}_{1}\right) \mathrm{C}_{6} \mathrm{H}_{3} \mathrm{NO}_{2}$ - and $\mathrm{s}_{1} \mathrm{C}_{n} \mathrm{H}_{3} \mathrm{CH}_{3}+\left(1-\mathrm{x}_{1}\right) \mathrm{C}_{2} \mathrm{H}_{3} \mathrm{NO}_{2}$ at a temperature of $303.15 \mathrm{~K}$. The terms $\mathrm{T}, \wedge \mathrm{N}$. NP. and NF. inset represent the toluene, acelonitrile, nitrobenzene and nitrocthane respectively.

the liquid mixtures may be due to presence of different ionic interactions or arrangements within the mixtures. The following discussions have been made for this.

According to Fort and Moore. ${ }^{2-t}$ a negative excess volume is an indication of strong heteromolecular interaction in the liquid mixtures and is attributed to charge-transfer. dipoledipole. dipole-induced-dipole interactions and hydrogen bonding between the unlike components. while a positive sign indicates a weak interaction and is attributed to depersive force (London forces), which are likely to be operative in every cases. The magnitudes of the contributions made by the different types of interactions will vary with the components and composition of the mixtures. In the present imvestigation, however, all the three mixtures gave negative magnitude of $\mathrm{V}_{\mathrm{m}}{ }^{\mathrm{F}}$. depict the presence of heteromolecular interac- 
tion in all the binary liquid mixtures, which support the Fort and Moore observation.

The $\mathrm{V}_{\mathrm{tu}}{ }^{\mathrm{F}}$ (Figure 1) for $\mathrm{C}_{6} \mathrm{H}_{3} \mathrm{CH}_{3}+\mathrm{CH}_{3} \mathrm{CN}$ mixtures can be explained as (i) specific interaction between the unlike molecules. and (ii) geometric effect due to difference in molar volumes. In $\mathrm{C}_{6} \mathrm{H}_{5} \mathrm{CH}_{3}+\mathrm{CH}_{3} \mathrm{CN}$ mixture, $\mathrm{C}_{6} \mathrm{H}_{5} \mathrm{CH}_{3}$ is a non-polar aprotic solvent. and the solvents that lies in the aprotic class are not effective in stabilizing the development of charge separation. The molecules of these liquids have small dipole moments and do not have protons capable of forming lyydrogen bonding. ${ }^{55}$ So in $\mathrm{C}_{6} \mathrm{H}_{5} \mathrm{CH}_{3}$ molecule. there is a possibility of interaction between nund 56 stems. In valence bond theory, a special type of resonance called lyper-conjugation is used to describe the interaction ${ }^{25} \ln$ valence bond language. "no bond" resonance structures are introduced to indicate this electronic interaction as shown below.

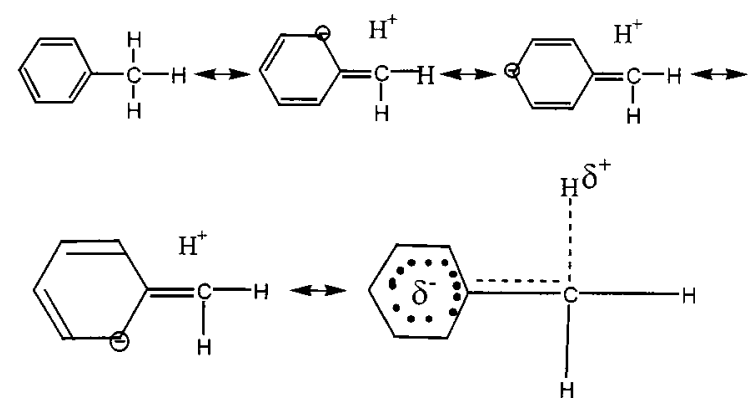

Due to this resonance. the negative charge on the methylene group of $\mathrm{C}_{6} \mathrm{H}_{3} \mathrm{CH}_{3}$ molecule is stabilized, so that the lydrogen atom has a positive charge and in $\mathrm{C}_{6} \mathrm{H}_{5} \mathrm{CH}_{3}+$ $\mathrm{CH}_{3} \mathrm{CN}$ mixture, there may be an interaction between hydrogen atom of the $\mathrm{C}_{6} \mathrm{H}_{5} \mathrm{CH}_{3}$ molecule and nitrogen atom of the $\mathrm{CH}_{3} \mathrm{CN}$. The interaction can be shown as follow:

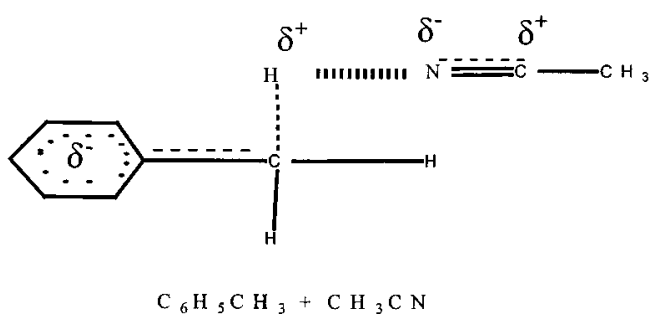

The $\mathrm{C}_{6} \mathrm{H}_{5} \mathrm{CH}_{3}$ molecule has an alternate $n$ bond system which overlaps to form a cloud of electrons located centrally above and below the ring. making it highly susceptible to interaction with electrophilic or electron deficient molecules. In $\mathrm{C}_{6} \mathrm{H}_{5} \mathrm{CH}_{3}+\mathrm{CH}_{3} \mathrm{CN}$ mixture, there would be dipoleinduced-dipole interaction between - $\mathrm{CN}$ group of acetonitrile and aromatic ring of toluene. The interaction is greater than the dispersise and dipole-dipole breaking interaction. A weak charge transfer complex may be formed due to the electron donor ability of the methyl group in $\mathrm{C}_{6} \mathrm{H}_{5} \mathrm{CH}_{3}$ and weak electron acceptor ability of the $\mathrm{CH}_{3} \mathrm{CN}$. which is a donoraceptor type of interaction. This results in negative $\mathrm{V}_{\mathrm{m}}{ }^{\mathrm{F}}$. Interstitial accommodation of small acetonitrile molecules (molar volumes +1.05 at 30 " $\mathrm{C}$ ) between the toluene mole- cules (molar volumes $92.1+$ at $30{ }^{\circ} \mathrm{C}$ ) may lead to a further decrease of the $\mathrm{V}_{\mathrm{II}}{ }^{\mathrm{F}}$ values. Dewan et al. ${ }^{\text {Yi }}$ reported the excess molar volumes of etly lbenzene + acetonitrile mixture at a temperature of $303.15 \mathrm{~K}$. They reported the negative values of $\mathrm{V}_{\mathrm{m}}{ }^{\mathrm{F}}$ but small positive values at very low mole fractions $\left(x_{1} \leq 0.002\right)$ of ethylbelzene were also observed. The general shape of our experimental $\mathrm{V}_{\mathrm{tII}}{ }^{\mathrm{E}}$ of $\mathrm{C}_{6} \mathrm{H}_{5} \mathrm{CH}_{3}+$ $\mathrm{CH}_{3} \mathrm{CN}$ as a function of mole fraction are good agreement with the reported values ${ }^{2 ?}$ for bezonitrile + toluene.

The $\mathrm{V}_{31}{ }^{\mathrm{F}}$ of (i) $\mathrm{C}_{6} \mathrm{H}_{5} \mathrm{CH}_{3}+\mathrm{C}_{6} \mathrm{H}_{5} \mathrm{NO}_{2}$ and (ii) $\mathrm{C}_{6} \mathrm{H}_{5} \mathrm{CH}_{3}+$ $\mathrm{C}_{2} \mathrm{H}_{5} \mathrm{NO}_{2}$ systems can be explained in the terms of (i) specific interaction between the polar nitro-compounds and the aromatic ring which behaves as an electron donor and (ii) steric effect. respectively: Introduction of a methyl-group in the benzene ring would increase the liable nature of the electrons of the aromatic ring of toluene. ${ }^{2 *}$ Therefore $\mathrm{C}_{6} \mathrm{H}_{5} \mathrm{CH}_{3}$ would interact strongly with polar $\mathrm{C}_{2} \mathrm{H}_{3} \mathrm{NO}_{2}$ molecules and result in decrease in volume of the mixture. Among the $\mathrm{C}_{2} \mathrm{H}_{5} \mathrm{NO}_{2}$ and $\mathrm{C}_{6} \mathrm{H}_{5} \mathrm{NO}_{2}$ molecules, the polarity of nitrobenzene is expected to be more than the nitro-ethane due to the replacement of electron releasing ethyl-group with a benzene ring and would be greater specific interaction in $\mathrm{C}_{6} \mathrm{H}_{5} \mathrm{CH}_{3}+\mathrm{C}_{6} \mathrm{H}_{5} \mathrm{NO}_{2}$ mixture resulting in a negative $\mathrm{V}_{30}{ }^{\mathrm{F}}$ value of greater magnitude. Relatively low electron cloud in $\mathrm{C}_{6} \mathrm{H}_{5} \mathrm{NO}_{2}$ than that of $\mathrm{C}_{2} \mathrm{H}_{5} \mathrm{NO}_{2}$ would allow more efficient packing in the $\mathrm{C}_{6} \mathrm{H}_{5} \mathrm{CH}_{5}+\mathrm{C}_{6} \mathrm{H}_{5} \mathrm{NO}_{2}$ mixture, leading to a further decrease of $\mathrm{V}_{10}{ }^{\mathrm{F}}$. Marsh et al. ${ }^{29}$ has reported $\mathrm{V}_{10}{ }^{\mathrm{F}}$ values for benzene + nitroethane at $298.15 \mathrm{~K}$. which are negative and sigmoid nature. The $\mathrm{V}^{\mathrm{E}}$ values reported by Dewan $e a^{26}{ }^{26}$ at $303.15 \mathrm{~K}$. It was positive for ethylbenzene + nitroethane mixture at $x_{1}<0.45$ and negative for toluene + nitro-ethane system.

\section{Conclusion}

The negative magnitude of the $\mathrm{V}_{\mathrm{tu}}{ }^{\mathrm{E}}$ suggests the presence of a intermolecular interaction in all the three binary liquid mixtures and subsequently presumed that the weak electron donor acceptor interaction for $\mathrm{C}_{6} \mathrm{H}_{5} \mathrm{CH}_{3}+\mathrm{CH}_{3} \mathrm{CN}$ and the specific interaction between the polar nitro-group of the $\mathrm{C}_{4} \mathrm{H}_{3} \mathrm{NO}_{2}$ and the $\mathrm{C}_{2} \mathrm{H}_{3} \mathrm{NO}_{2}$ with the liable $n$ electrons of the aromatic ring behaved as an electron donor. The study also shows that the ability of interaction of the nitro-group of $\mathrm{C}_{3} \mathrm{H}_{3} \mathrm{NO}_{2}$ with $\mathrm{C}_{6} \mathrm{H}_{3} \mathrm{CH}_{3}$ is greater than that of the $\mathrm{CN}$ group of $\mathrm{CH}_{3} \mathrm{CN}$ with $\mathrm{C}_{4} \mathrm{H}_{3} \mathrm{CH}_{3}$ and the $\mathrm{NO}_{2}$ of $\mathrm{C}_{2} \mathrm{H}_{5} \mathrm{NO}_{2}$ with $\mathrm{C}_{3} \mathrm{H}_{3} \mathrm{CH}_{3}$.

\section{References}

1. Tresczanomic, A. J.; Benson, (i. C. J. (hem. Thetwodt: 1978, /0, 967.

2. Kumaran, M. K.; Bensom, G. C. J. Chem. Themody. 1983, /5. $24 \overline{5}$.

3. Rajkumar. X. R.: Raman. K. V.: Anulrạ. S. T. Actor Cienc. Indica (Ser) Chm. 1981. 7(1-4). 967.

4. Tresczanomic, A. J.: Kivohara, T.: Benson, G. C. Bull . Lad Poly Sci. Sir Sci ( Whm 1981, 29(1-2), 103.

5. Rajkumar, X. R.; Raman, K. V.: Amulaj. S. T. Ind. . Fun? .1ppl. 
Phos. 1984. 22. 241

6. Orgela. J.: Angula. M. C. Chm. Eng. Data 1984. 29.340.

7. Rive. O. K. Chem. Rev 1949, 44.69.

8. Scotchard G. Chem. Rev. $1949,4+7$.

9. I Jildebrand, J. I I. ('hem. Rev 1949. Ht, 37.

10. Stokes, R. II.; Marsh. K. II. Amh. Rev. Phws. (hem. 1972. 23, 65.

11. Kian. Y. S.: Gerritan. J. K.: Noore. N. Y. Th'rmophisical Propertics Restarh Liferature Refrieval, Guide: l'lemnum P'ress: New york. 1967.

12. Irving J. B. WI. Report. Fo. 630 and 631 : Fast Kilbridge: Glasgow, 1967.

13. J akhanpal, M. J.: Ali, M. A. Ifd . J. (hem 1987. 26. 648 .

14. Ali. M. A.: l'raser. R.: Sharma. A.: Lahlanpal. M. L. Ind. J. Ch'm. 1989. 28.512

15. Ali. M. A.: Mahmud. M. J.: Rahiman. M. H.: Rouli. M. A.: Islam. M. S. J. Bangla Chem. Soc. 1990, 3. 17 .

16. Ali. M. A.: Praser. R.; Marlana, R. K.: Jakhanpal, M. I. Ind $J$. ('hem. 1990, 29, 177.

17. Ali. M. A.: Rahmann. M. H. J. Bongho. Chem. Soc, 1992. 5. 109.

18. Ali. M. A.: Lakhanpal. M. L.: l'rashar. R. J. Bamgla. Chem. Soc.
1991. 1.175

19. Prashar. R.: Ali. M. A.: Metha. S. K. J. Chem. Thermoch: 2000. 32.711

20. Weast. R. C. Itandhook of (hemistry and Phusics, $5^{\text {lh }}$ ed: CRC Press Inc: Boca Raton, Forida. 1975-76,

21. Riddick, J. A.: Bunger, W. B.: Satnako, T. R. Organic Solvent,

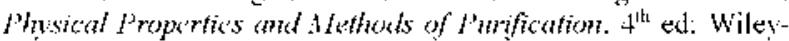
Intersci.: N. Y.. 1986.

22. Ali. M. A. Ph. D. Thesis: l'anjab University; Chandigsar. Indiat. 1985

23. Redlich, O.: Kister. A. T. Indus. Fng. (Wem. 1948, 40, 345

24. Fort. R. T: Moore, W. R. Trons. Forad Soc. $1966,62,1112$.

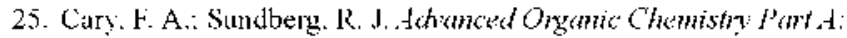
Sinctum and thechamism. $3^{\text {rol }}$ ed: Plenum P'ress: 1990.

26. Dewan. R. K.: Metha. S. K. J. Chem. Themer. 1985. 18.176.

27. Fimmerich, W.: Fgger. W.: Vencour. M.: Roux. A. II.: Polednick, M.: Grolier J. P. F.. J. Chem Thernots 1998. 30. 1509

28. Nigam, R. K.: Singh. K. C. J. Chem Soc. Foma Trons. I 1979. 75.1120 .

29. Marsh. K. N. J. Chem. Themoch 1995. 17. 29. 